\title{
Towards an Inclusive Model of African Regional Integration: How Effective has the Linear Model been
} so Far?

\author{
Hannah Muzee ${ }^{1}$, Andrew Osehi Enaifoghe ${ }^{2 *}$ \\ ${ }^{1}$ Humanities and Social Sciences, Pan African University, University of Yaoundé II, Soa, Cameroon \\ ${ }^{2}$ Department of Public Administration, University of Zululand KwaDlangezwa, South Africa \\ Muzhann2002@gmail.com, andyransey@gmail.com
}

\begin{abstract}
The proponents of African regional integration hoped to create large economic spaces that allow economies of scale, increased efficiency, competitiveness and faster growth of Africa states. Whereas the linear model of regional integration seemed to have worked for the European Union, many have questioned its applicability in the African context. The applicability of the Linear model at the stages of Regional Economic Communities (RECs) like the EAC has met with significant stagnation primarily because of some bottlenecks such as poor infrastructure that limits the connectivity with the continent and lack of political will out of fear for the loss of sovereignty. The question thus lies in how the dream for a regionally united Africa will arise when its people cannot move and interact freely within the continent? By utilizing a secondary research design, this paper, therefore, sought to not only examine the effectiveness of the linear model of regional integration for Africa but also explore the possibility of incorporating the functionalist and federalist approach into an inclusive model for African regional integration. In examining the economic dynamics of regional integration, the paper identifies the benefits of economic integration, such as larger markets as a result of free movement of people and goods that could be harnessed by trading communities within Africa. Thus, the central argument in this paper does not discard the benefits and successes of the linear model of regional integration but concludes that its effectiveness can be enhanced by incorporating functionalist and at later stages federalist approaches to regional integration in Africa. The principal argument is that political and elitist integration agreements are futile when the continent is not connected physically and trade wise.
\end{abstract}

Keywords: Development, Functionalism, Federalism, Linear-model, Regional-Integration, Economic growth

\section{Introduction}

African integration is rooted in the spirit of Pan Africanism and African Renaissance. The OAU and Economic Commission for Africa spearheaded the uniting of Africa into a regional block in the 1960s. They aimed to unite Africa by promoting political and economic progress on the continent and developing a united bargaining force against imbalances in the international system (Qobo, 2007). Besides, the proponents of African regional integration hoped to create large economic spaces that allow for economies of scale, increases efficiency, competitiveness and faster growth of Africa states (Chingono \& Nakana, 2009). Tanyanyiwa \& Hakuna, (2014) acknowledged that the continental hope for poverty reduction and economic development rests upon Regional integration. This is further emphasized by the African Union (AU) goal of establishing an African Economic Community by 2028. Against this backdrop, Hartzenberg, (2011) observes that African regional integration schemes tend to be generally ambitious with unrealistic timeframes towards deeper integration and in some cases even a political union. In order to achieve its objective, Africa through the $\mathrm{AU}$ has adopted the linear model of integration. The model of integration is also followed by the Regional Economic Communities (RECs) which are considered the building blocks of African integration. However, like Hartzenberg, other scholars McCarthy (2010) doubt the applicability of the linear model for the success of African Integration.

It was maintained by Enaifoghe and Adekoye (2018), that "the final product of a system of the political combination is another political group, superimposed over the pre-existing ones. It is no doubt that regional integration has shown itself verifiably in Africa, America, and Europe as a bureaucratic push to encourage political unification and expansion of capitalism". One of the sub-regional integration that was "revitalized in some ways is the South Africa regional collaboration in Southern Africa mainly because of two major developments that happened at the beginning of the 1990s, this included the abolition of the apartheid regime in South Africa and eventual stabilization of political and economic relationships in the Southern Africa sub-region." Since the end of the Cold War, and with the rise of capable exchange coalitions, there has 
been a renewed interest in South Africa regarding the need to create robust Real Economic Impact (REI) mechanisms to promote economic growth for the region and by implication foster South Africa's National Development trajectory (Enaifoghe and Adekoye, 2018). Nevertheless, this study, therefore, aims to examine an inclusive model of regional integration for Africa.

It considers the contribution of the functionalism and federalism theories of integration. It also aims to examine the effectiveness of the linear model of regional integration thus far in Africa and give recommendations. This will begin with a review of the two theories of functionalism and federalism showing their relevance to the African context. It will then examine the linear model, explain the inclusive model and give recommendations. The objective of this study sought to not only examine the effectiveness of the linear model of regional integration for Africa but as well explore the possibility of incorporating the functionalist and federalist approach into an inclusive model for African regional integration, in order to reap true benefit from an integration using the linear model.

\section{Theoretical Considerations}

Functionalism posits that integration is as a result of the focus on "social and economic issues such as trade, communication, health, sanitation, nutrition, scientific and technological spheres" (Ibrahim et al., 2015). The authors add that functionalism is based on the assumptions that: integration derives from the technical, social and economic sphere and not political spheres regarding a supranational entity. It is also based on the assumption that organizations are focused on task requirements that increase the welfare rewards of individuals beyond the level that the states can afford to attain and lastly functionalism is based on the assumption that an individual's loyalty is weaned from the state by experiencing the fruitful, international cooperation in technical and functional areas. Bolanos, (2016) stated that functionalism is based on the view that "society as a complex system with diverse works together to promote solidarity and stability". Hence, Hartzenberg (2015)'s an assertion that integration is a process that requires the combined efforts of traders, workers, and consumers. Therefore, it not being an entirely elitist driven process and African, needs the contributions of every possible individual for integration to be successful. The challenges of Africa such as: peace and security, the rule of law, political instability, economic development, Kühnhardt (2005). The free movement and extension of goods and services beyond borders will deepen integration in the continent.

Remarked are beyond the capacities of individual states and thus necessitate that integration systems emphasize functional deepening insecurity and parliamentary representation, human capacity building so as to enhance the quality of integration in Africa. Kuhnhardt further added that successful regional integration would require a solid preparation of individual member states for regional grouping because weaker states only provided a weaker integration. Whereas the European Union (EU) started from functional cooperation in the area of mining, African integration on the other hand was initially motivated by a political vision of African Unity and later developmental reasons that necessitated rising above the "challenges of small markets, landlockedness and the need to benefit from economies of scale in production and trade" (Tanyanyiwa \& Hakuna, 2014). Most importantly, it is difficult for most of these challenges to be alleviated unless the continent is physically interconnected. Physical interconnection or integration requires the construction of communication channels by connecting transport energy and telecommunication networks which will link more than one country (Bolanos, 2016). This Bolanos argued will support economic integration (Africa is concentration right now) which will guarantee long-term sustainability of the integration scheme. Physical integration Bolanos also claims it will increase productivity by lowering production costs and extend the trade of good and service. This will strengthen the essence of integration as the unification of many independent units into a meaningful whole (Chingono \& Nakana, 2009).

Thus similarly Haas, (1970) noted that integration was an institutionalized procedure decided by governments for coping with the condition of interdependence. Consequently, Hooghe \& Marks (2005) asserted that functionality is the engine for integration and politicization determines whether, when and how functional pressures lead to regional integration. Alexandrescu, (2007), notes that any unification aims to bring about a peaceful international system. Alexandrescu further notes that functionalism involved how states could converge to develop some fields, ignoring the limitations of political geography. According to Magu (2014), Mitrany's functionalist ideology is bent on regions and institutions doing things together in the marketplace rather than just signing pacts in chancelleries. The functionalist approach advocates for 
integration starting from technical and non-controversial sectors, positing that gains in one sector will eventually spill over to other functions like economic and political issues. Unlike Africa, this is what the EU focused on (Sore, 2010). Sore recommends that like the EU, the AU should focus on investment in critical sectors like education, health, infrastructure, and agriculture. For functionalism, priority is given to cooperation rather than integration (Kurt, 2009). Kurt further observes that the idea of internal dynamic cooperation on which functionalism is based on is premised on the fact that if states work together in certain areas or sectors by designing new bodies to direct that particular cooperation, then this will eventually lead to cooperation in other sectors by means of an invisible hand of integration. Kurt, (2009) stated that this invisible hand of integration arises out of the creation of international integrationist institutions which are seen as an acceptance of forces that initially drove states into the surrender of sovereignty. Functionalism involves a transfer of a country's economic sovereignty to an international executive agency serving on behalf of the member countries (Alexandrescu, 2007). These transnational bodies Kurt argues are more efficient in providing human welfare than national governments. The Economic Commission for Africa ECA (2006) emphasizes that flexibility is the key to African integration. It argues that Africa needs to experiment with flexible institutional designs that have worked elsewhere for as long as they fit into the socio-political and economic fabric of the continent, hence the proposition of a functionalist approach towards African integration. Since functionalism emphasizes technical experts and technocrats over politicians (Kurt 2009), and as recommended by the ECA, it fills the institutional vacuum in areas of agricultural, industrial and competitive policy and creates a need for regional economic communities to provide institutional support where national governments are weak. Functionalism assumes that states are insufficient in meeting citizen's needs and thus the need for transnational bodies that will facilitate in problem-solving at a global level hence encouraging growing interdependence among states (Kurt, 2009).

Functionalism eliminates the state by seizing its functions through "a welfare-oriented myriad of functional entities" (Chime, 1977). Chime further notes that Functionalists forsake the constitutional approach of federalism and concentrate on the functional approach. They "capitalize on welfare, economic and social organization at the expense of politics. While the constitutional approach emphasizes the individual index of power, the functional approach emphasizes the common index of need" (Mitrany, 1948). Chime adds that for functionalism, the central concern is needs and that the recognition of felt needs creates functional entities and on the downside become defunct once those needs are met or subside. Therefore, as Zormelo (1994), notes functionalism proposes that national and international activities go along the functional lines. That individuals with shared needs come together to perform tasks that mutually satisfy those needs. Hence, Mitrany, (1966) suggests that public action should be taken with democracy in mind, regarding the need for a collective action that is evident and acceptable by all parties for the common good. Mitrany, (1948) further added that since functional arrangements have the virtual of technical self-determination, this makes it readily acceptable. Thus, whereas early proponents of African unification sought a "political kingdom" without building functional areas, this paper proposes that Africa considers building its functional capacity first and then move towards a political union.

However, functionalists tended to look with suspicion at regionalism and viewed it as a hindrance to global development. To functionalists, the end product is a network of functional agencies stretching over the globe, sidetracking politics, eliminating war and rendering the nation-state superfluous (Chime, 1977). However, political leadership at some point is inevitable, and Chime observes that although functionalists do not envisage a federation, they recognize that it might serve their aim hence the relevance of federalism to a functionalist agenda. Federalism is the division of sovereign authority among levels of government (Eskridge et al., 1999). In federalism, each government is sovereign in its sphere (Hazlewood, 1967). Federalism is also a system by which states create an entity to which they relinquish their sovereignty in parts or whole for collective gain (Ibrahim et al., 2015). The authors also note that a federation could constitute an intergovernmental unit in a narrow sense with a combination of self-rule and shared rule through constitutionalized power sharing in a non-centralized basis in the broader sense. The federalism theory assumes that: regional integration derives from the need for a region cohesion anchored in unity in diversity rather than the existence of different competing states; it assumes that states have lost property rights since they cannot guarantee political and economic safety of their citizens and that ideal continental unity is a political goal; it also assumes that states exercise local autonomy in appropriate fields of policy within the territory (Ibrahim et al., 2015; Bergmann \& Niemann 2013). 
Moreover, Ziblatt (2004) in accord with one of the assumptions of the federalism theory states that federations form through a combination of coercion and compromise. Chime (1977)) states that "a strong federal system requires three important characteristics; a precise allocation of power between the states and the federation and that the state powers" tend to be significant a robust federal system requires a range of supportive institutions like the constitutional court. That there should be a distribution and division of powers within the federal states such that each is within a sphere, co-ordinate and independent. Chime adds that with Federalism allocating demarcated "powers to units in a national system, it seeks to preserve the virtues of local autonomy, diversity, and freedom". Hence for federalism to be successful, it needs to be carried out in a context of pre-existing units of a potential federation that are highly institutionalized and deeply embedded in the society (Ziblatt, 2004).

For the case of Africa, that is multi-ethnic; Federalism is considered an appropriate framework for such societies (Ojo, 2009). Ojo notes that federalism is reputed to be an effective political-constitutional design for managing complex government challenges usually associated with ethnic and cultural diversity. Federalism is also considered to be suitable for enlarging governments. It is a system that can accommodate communities of different political taste and protect political liberties at the same time (Beramendi, 2007). It further added that federalism is presumed preferred because it prevents large-scale governments from imposing the 'tyranny of the majority' upon political liberties. Rothchild, (1968) notes that African politicians are freer to join or not to a federation because interest groups in Africa are neither as powerful nor as transnationally oriented as in Europe. However, Rothchild (1968) remarked that for federalism to be applicable, it requires an adequate, geographical-based diffusion of power, favourable ethos, a climate of political tolerance, and a sense of community, and a myth of potential benefit.

Kühnhardt, (2005) too observes that without trust in the honesty, sincerity, and objectives of one's partners no regional building initiative will be successful. Kuhnhardt further noted that successful regional building requires mutual recognition of the governance regime of all partners in a regional grouping. Consequently, federalism brings together previously separate autonomous territorial units to constitute a new form of union with the central authority in which the units retain some power (Bergmann \& Niemann, 2013). The authors further add that federalism involves incorporation of regional units in the decision-making procedures. Hveem, (1974) posits that the federalists emphasize the creation of an international institution through the correct division of power between supranational organizations and the national institutions. Thus, Chime (1977) acknowledges that "federalism upholds the right of securing a political union by a dramatic and immediate subscription to a blueprint for allocating powers to the system and the units". Accordingly, Mitrany, (1948) stated that federalism rested on a rigid division of power and functions between territorial authorities which have equal status.

Mitrany further suggests that federalism also helps to mitigate the problem of equal sovereignty by pooling as much as is needed for the joint performance of a particular task. Therefore, Federations succeed once regional governments do not try to take advantage of one another and the central authority does not try to usurp power from the regions (Eskridge et al., 1999). Inversely, Hamad, (2016) stated that a political federation through inter-governmentalism allows for member states to retain their sovereignty. For the EU surrender of sovereignty was difficult but it was handled through a functional approach that didn't directly compromise on state sovereignty. For Africa, states insist on respect of their sovereignty, and this has impeded the progress of the $\mathrm{AU}$ hence the suggestion of a functionalist approach before federalism. Federalism is possible for Africa only if applied from the functional perspective. Bergmann \& Niemann, (2013) mention two types of federalism; classical federalism which involves a dramatic act of constitutional revolution initiated by political elites and decided through formal rules, and functional federalism which achieves integration through a gradual process of forging functional links between states in areas with unchallenged national sovereignty. Mitrany, (1948) too adds that federalism brings together countries that are adjacent for a general purpose while retaining their separate identity.

Chime, (1977) argued that although federal theorists believe in a federal end, they may be willing to use functional means to get there. Regards to federalism, a supranational body-political community is the end state of integration. Hamad, (2016) on the other hand, recognizes two types of political unification a one-tier system (a supranational organization with a single president and common policies across the region) and 
two-tier system (an inter-governmental organization with a single president and shared economic and security policies among member states. Hamad remarks that most heads of states would most prefer the latter for sovereignty reasons. This point leads to the culmination of a political integration were many governments begin to create and use shared resources committed in the pursuit of specific common objectives (Lindberg, 1970). Lindberg defines political integration as the evolution over time of a collective decision-making system among nations. Both approaches of the functionalist and federalist "subscribe to a supranational state as the end point" of an integration process (Chime, 1977) and not as a starting point.

\section{Method and Materials}

Qualitatively this research allowed the researchers to study and make sense of written or documented materials, which may be available in the public or private domain (Mogalakwe, 2006). This recommends that researchers are only able to determine the relevance of the documents consults from their significance to the study. Furthermore, (Dey, 2005, p.105) argues that "in qualitative analysis, a certain criterion is set or determined by the researcher for selecting documents, or for focusing on particular extracts, which should reflect the issues on which the researcher is seeking evidence." This method made it possible for the researchers to explore the factors responsible for the African integration which viewed to be rooted in the spirit of Pan Africanism and African Renaissance. The uniting of Africa into a regional block as the OAU and Economic Commission spearheaded it for Africa in the 1960s.

The primary study objective looks at the linear model with regards to trade, which led to a process of economic integration; it was expected to lead to the complete economic union of Africa. It is comprised of the Free Trade Area (FTA) as the first stage, through to the Customs Union (CU), Common Market (CM) and lastly the Economic and Monetary Union. This study, therefore, looks at the Inclusive Model of African Regional Integration, and to find how effective has the Linear Model been so far in the achievement of African integration. Thus, the central argument in this paper does not entirely discard the benefits and successes of the linear model of regional integration but concludes that its effectiveness can be enhanced by incorporating functionalist and at later stages federalist approaches to regional integration in Africa.

\section{The Economic Dynamic Effects of Regional Integration}

Generally, it is not all welfare impacts of the regional monetary combination or integrations are static. They are likewise dynamic and powerful impacts which can affect a member nation's long-term development rates. These incorporate as indicated by the hypothesis of optimum or ideal currency, are to be gotten from sharing money over nations' fringes (Carbaugh, 2004). These economic gains incorporate more uniform costs bring down trade and exchange expenses, and conviction for financial "investors, economies of scale, factor efficiency and improved rivalry. The dynamic additions of regional monetary coordination stem or curtail basically from the making of bigger markets by the development to more liberated exchange under custom unions" (Carbaugh, 2004). On a fundamental level, economic and financial combination joins markets, making it conceivable to diminish restraining infrastructure control, as more firms from various nations are carried into more serious rivalry with one another. The advantages related to a customs union's dynamic increases could balance out any negative static impacts. It was argued, "that nations, whose pre-union economies were more specialized are probably going to profit more by integrating" (DeRosa, 1998).

Tovias, (1992) sees it from another viewpoint that few authors' concluded that a nation that trades with its prospective partner before the arrangement of an association was probably going to gain from synchronization. This is genuine except if the last can enhance their positions of exchange with the rest of the world through exchange redirection or diversion. In any case, the enhancement of terms of exchange relies upon the extent of the association in connection to different nations. The bigger the size and more noteworthy the number of nations in the association, the more prominent the additions are probably going to be. Furthermore, market amplification additionally enables firms to abuse economies of scale all the more thoroughly. Tovias, (1992) noted that "there is a trade-off between economies of scale and rivalry, which is if organizations are bigger there are less of them, and the market is less aggressive." Developing the market moves this trade-off, as it ends up conceivable to have both more prominent organizations and more rivalry. If a RIA can build the force of rivalry, at that point, it might instigate organizations to dispense with central 
wasteful aspects. For this situation, the essential inquiry is regardless of whether Africa will have the capacity to exploit these advantages. Even though the effect of the territorial joining of integration on development has been hard to evaluate, the hypothesis of endogenous development should give Africa trust.

This hypothesis recommends that the development rate of an economy is mainly influenced by the financial and economic approaches, the rate of mechanical advancement and learning aggregation, and also the nature of foundations and administration. In such a manner, the ECA (2004) has bolstered this endogenous development hypothesis by demonstrating that territorial financial incorporation and integration can add to monetary development by amplifying the effect of three variables. Initially, the exchange frequently connects with mechanical overflows, because a nation can import innovation and learning grew abroad. In this manner, by invigorating exchange, territorial financial combination and integration can build the rate of mechanical advancement. Thus, the central arguments in this paper, does not entirely discard the benefits and successes of the linear model of regional integration but concludes that its effectiveness can be enhanced by incorporating functionalist and at later stages federalist approaches to regional integration in Africa. Foreign Direct Investment (FDI) (as one of the dynamic economic gain of coordination animated by a vast market) can likewise channel innovation and information crosswise over fringes or border, and as local combination advances FDI the mechanical.

The second factor is holding fast to particular macroeconomic assembly criteria and compelling nations to make a macroeconomic situation that is steady of worldwide rivalry. Hence encouraging sound monetary results, for example, low swelling and inflation, low shortfalls and predictable trade rates. The third factor is that, as a significant aspect of reconciliation and integration, member nations are regularly required to refresh and enhance regulatory and administrative structures - another issue regarding the effect of the territorial financial combination on development concerns destitution lightening the alleviation of poverty. This connects to the customary view that quicker development may convert into scattered pay conveyance, and have ramifications for the alleviation of poverty. In any case, the ECA (2004) presented some counterevidence which proposes that the development rate of normal wage is coordinated precisely by the development rate of the pay of poor people. Along these lines, regional monetary integration could advance development and decrease destitution and poverty. Another contention is that regional coordination can have an effect on income convergence across nations.

Schiff and Winters, (2003) have shown that, even though the adjustments in exchange and trade have turned out to be of significant advantage to the economies concerned, not all exchange changes originate from regional coordination. In testing the noteworthiness of changes in impacts, they have searched for three separate impacts as far as the exchange of each RIA: consequences for intra-bloc exchange, extra-bloc imports, and extra-bloc trades. They discovered that in RIAs between developing nations, the advancement of exchange over a specific period seems to have been overwhelmed by outer liberalizations. Nevertheless, contrary to what is argued above by Schiff and Winters that "there appears to be a consensus that regional economic integration offers developing countries substantial benefits." This consensus based on the evidence provided by the ECA (2004), as a positive, impacts trade liberalization has on efficiency, through economies of scale and expanded rivalry. The ECA group this kind of agreement into two. The first consensus shows that a large number of these advantages can be accomplished through exchange progression or development. Moreover, secondly, the full acknowledgement of these advantages expects firms to take part in a more straightforward and extreme rivalry. This implies that member nations must actualize profound coordination in order to benefit from a linear approach to regional integrate fully.

Examination of the Linear Model of Regional Integration for Africa: The linear model is a trade-led process of economic integration that is expected to lead to the complete economic union. It is comprised of the Free Trade Area (FTA) as the first stage, through to the Customs Union (CU), Common Market (CM) and lastly the Economic and Monetary Union (AEC, 2006). The AEC recognized that the Linear Model an EU blueprint for integration cannot be followed to the latter due to the specific socio-political, economic circumstances. It is also on this basis that this paper proposes an inclusive model with a slight modification incorporating the linear model. It may, however, be entirely unrealistic to disregard the linear model, because it has achieved some gains, but it is because of its downsides that this paper proposes the incorporation of the functionalist and federalism approach. According to McCarthy, (2010) in Jawoodeen, (2010), the linear model 
is a sequential process that allows for incremental changes and for members discretion to proceed at their own pace. Jawooden noted that many trade agreements do not follow the linear process. This is because particular criteria need to be met before one move to the next stage and this makes it hard to deepen integration while following this process, for instance, the movement to a CU requires countries to give up its revenue from customs, and yet most African countries depend on customs revenue.

McCarthy, (2010) observes that it is impossible to achieve deeper integration with poor economies that design and implement poor policies and have a weak institution in place. McCarthy believed it a fallacy that Regional Integration could be implemented and managed by states that are weak in policy, governance institutions and cannot produce tradable products competitively. For instance; SADC as one of the RECs in Africa has got good quality institutions, efficient goods, labor markets, and well developed financial institutions but poor health and education sectors and generally a low level of technological capacity. East African Community (EAC) although with the well-developed market, suffers the lack of proper infrastructure, macroeconomic stability together with poor health and education indicators. The ECOWAS on the other hand although with strong institutions and innovation is also besieged by weak health, education and infrastructural development. McCarthy, (2010) recommends a commitment to schemes that will contribute to the development of competitiveness and capacities on the supply side of economies like transport infrastructure and communication services. Sakyi \& Opoku, (2014) to affirm that especially for Africa, the challenges to regionalism and economic integration range from transportation and mobility of factors of production.

Multiple memberships and duplication of programs and procedures, minimal intra-regional trade to macroeconomic divergence and conflict these the Functionalist approach proposes as initial starting points for cooperation and consequent integration among states. Because the linear model is an economic model of integration, for Africa, economic integration tends to be besieged by many problems including; overlapping membership, unfulfilled commitments, unrealistic goals hence requiring a reconsideration of the process (Draper, 2010). Sakyi \& Opuku, (2014) assert that transport is imperative to the smooth functioning of regionalism and economic integration; people need to be able to move around quickly without any structural impediment. They too add that multiple memberships make it hard for countries to meet their obligations thus stalling the process of integration especially when it means moving from stage to another. Tsikata \& Melo, (2014) inversely, argued that for Africa if economic unification was to work out and contribute to development, it required a political union. Importantly, a pursuit for political union regardless of its downsides has been the goal of African regional integration, right from the 1960s, Hence the need for Africa to prioritize on its functional areas as a foundation for integration, the OAU charter 1963 and the Lagos Plan of Action (LPA) 1980.

Their failure led to the AEC treaty of Abuja in 1994 that planned to achieve African integration through the six stages of economic integration using Regional Economic Communities (RECs) as the building blocks (Hailu, 2014). Hailu however, claims that the AU endeavors to use RECs as building blocks for African integration will be fruitless so long as African states remain fragmented due to the low level of infrastructure development and state-centred nature of integration efforts. Additionally, argued that the lack of political motivation is one of the driving factors behind the slow progress of regional integration in Africa and is responsible for the overlapping memberships. As noted by Geda \& Kibret (2002), its time, African countries reconsider integration not as just a lingering pan African ideology but as a means for economic survival and a strategy for combating African marginalization from the global world. Furthermore, Geda and Kibret claim that unwillingness to surrender sovereignty is one of the reasons why African integration is stalling and yet increased cooperation is necessary among African states and one of the major precursors for intra-regional trade and consequently deeper integration (Hazlewood, 1967).

The Inclusive Model of Liner Integration: Regional integration has been seen to be "the way forward in Africa as there are numerous regional externalities that must be tended to through local collaboration". The proposed Continental FTA (CFTA) and the Tripartite FTA (TFTA) are the most recent African activities towards regional and territorial participation. It is believed that to succeed; these need to go up against an extremely uneven dispersion of assets that have honed the exchange off between the advantages of systematic approaches expected to handle cross-outskirt externalities and their costs which are increased by 
the sharp contrasts in arrangement inclinations crosswise over individual nations. Relinquishing the direct linear model of joining integration and coordinating in small gatherings should help in many ways. In the light of the execution of the Economic Community of West African States' (ECOWAS) in the West Africa with common external tariff (CET), there witness the dispatch of the Tripartite Free Trade Area among 26 nations, representing over about half of Africa's GDP and, with 632 million individuals, 56 percent of the population of the continent. A Continental FTA which is the Stage I of the TFTA proposes unobtrusive endeavours at incorporation as it is based on the standards of variable geometry shunning a more yearning 'single exertion' and the acquits with the modest levy decreases on the table. A rundown which was as opposed to an allinclusive basis, for principles of origin, exchange solutions for location dumping, and import floods.

African Regional Integration Effort, Beyond the Linear Integration Model: The establishing of the "Organization of African Unity (OAU) in 1963, which marked the first wave phase of the RIAs occurred along regional economic communities (RECs) behind high exercise duty". These RECs were meant to be the 'building blocks' of the sought after African association in the post-colonial period. Presently, they play an integral part in the actualization of the New Partnership for Africa's Development (NEPAD). The first wave fizzled for economic and financial reasons, as a result, that the pioneers of the post-independence African states were hesitant to support the development of a supra-national proficient, which was quite imperative to extend the relationship to deal with the African Union plan. Huge diversity in the RIAs converted into various interests that fortified nations' emphasis on the 'regard for the sway and regional uprightness of "each State and the basic appropriation to free manifestation,' as written in the Organization of African Unity agreement of 1963". Responsibility to skillet "Africanism" was debilitated, prompting dubiousness and a large number of announced destinations in these RIAs that helped states disregard the issues that isolated them (Melo and Laski, (2015).

The plan for stage II was yet to be set. However, it ought to incorporate administrations and harmonization of principles on rivalry arrangement. The TFTA is relied upon to be confirmed by the individual member, so, all things considered, it will come to life (Luke, David, and Zodwa Mabuza, 2015). The Abuja Treaty of 1991 began the second wave of RIAs in Africa. Taking a glance at the ten striking Regional Integration Arrangements (RIAs) according to Melo and Laski, 2015), in the "second wave of RIAs demonstrates that only about three have completed the FTA status, and all others going for more deep integration". With the coordination of integration moving along the direct linear model after stepwise incorporation of products, work, and capital markets, this will, in turn, end up in the monetary and financial combination of integration. However, the FTA integration would likely begin with an 'imports market,' then proceed onward to a customs union (CU) with a standard common external tariff or duty and to a typical common market. Along with this straight linear grouping except for the Southern African Customs Union (SACU), none have genuinely achieved full Customs Union (CU) status. Furthermore, the ECOWAS for example, CET incorporates a "special cases list" of around 300 items qualified for exclusion from the new duties that incorporates 200 items from the previous Nigerian Import Ban list (Melo and Laski, 2015).

Debatably, the frustrating exchange and trade execution of this linear model of joining integration has been broadly talked about. This among others is the evaluations of the volume of intra-territorial trade and exchange of African RIAs which recommend that exchange and trade are, by and large, 40 percent under the potential exchange. The proportion of genuine exchange to potential exchange among partners has fallen by $10 \%$. This invariably mirrors on the geography of African exchange trade, which also impacts on the low exchange complementarity crosswise over accomplices, poor coordination, and unnecessary delays in the border, and more so the disregard of administrations "in the African linear integration model is attuned to 21st-century exchange and trade". In the new condition, administrations play an information work through space, that is, transport, broadcast communications, and time - besides, coordinated contributions to a financial movement as they create learning and human capital. It is, therefore, argued that the on-going improvements in the investigation "of global value chains by the OECD prove that administrations may represent more than 50 percent of fares" when estimated in value inclusive.

Since administrations do not meet custom for enrolment, and controls are, incompletely fixed, administrations. Arguably, splitting in the direct linear model of the "Africa regional integration by underlining exchange help measures at the outskirt that have the full support of the business network" is an 
initial step now underway. Nonetheless, even on account of the East African Community Common Market, there has been little advancement at expelling limitations for expert administrations or services, communications, and transport either singularly or on a local premise. In like manner, advance with the progression of administrations through the harmonization and shared acknowledgment has been moderate where deciding on "common identicalness,' the course that was trailed by the European Union Services Directive may have worked better, as this methodology is less requesting on trust than universal acknowledgement or harmonization" (Melo and Laski, 2015). At this point, the AU will be acting as a facilitator of the integration process, just like the EU in the European Union in Europe today.

What Challenges are ahead in Dealing with Heterogeneity and Small Markets: The potential advantages of economies of scale and weakened imposing business model power present a case for RIAs to have broad participation, as found in the TFTA and the CFTA. Be that as it may, extensive participation likewise infers greater heterogeneity and more noteworthy wellsprings of potential clashes - ethnic gatherings, expansive and smaller nations, and with higher political expenses in the arrangement of open products. Insubstantial acceptance meetings, joining integration organization was regarded as shallow since it is hard to achieve assertion, and it is likely that the interests of an influential member that is usually less open to the outside world will win. Take a look at the ECOWAS, where Liberia and Nigeria belong to the same organization. In this regards for Liberia, according to Melo and Laski, (2015), the idea to "move to the CET, could double the normal duty and raise the current expenses of living for rural and urban family units by 6 percent and 3 percent, separately". With impermanent unique insurance estimates made-up for items presently, over their particular set, yet no thought is given for taxes beneath their band. It is observed that one of the challenges is the experience above epitomizes a trial for the 26 part TFTA because 21st-century regionalism is never about the trade of market access to the detriment of non-individuals. However, it is about actualizing changes that will pull in Foreign Direct Investment (FDI), which conveys to the local supervision exercises essential to partake in the redistributing of the group.

In this new condition, where the exchange is exchanging assignments and progressively includes a trade of middle of the road merchandise, insurance -trade of market get to, sums to denying oneself support in worldwide re-appropriating. Not exclusively is a profound joining of integration, which is essential to pull in FDI, this is prone to be difficult to complete in a substantial enrolment. However, there is additionally the hazard that security towards non-individuals could stay high. Profound combination necessitates some locus of power to a supranational level. This is less demanding to do with little participation. "The five-part EAC, which in 2010 began executing a typical common market in the capital, merchandise, and administrations, utilizes a scorecard approach to measure progress". The last is the current promotion of competition in telecommunication as they are banning roaming charges in the sub-region and issue of single tourist visas to countries of Rwanda, Kenya, and Uganda. Finally, in a nutshell, the argument therefore as proposed in this paper is that if indeed Africa is to reap the full benefits by reaching its full potentials as a regional organization, the African Union should begin by building functional areas within Africa. Such as infrastructural development, agricultural development, ICT, energy and power development, and human capacity building regarding skills and training in higher education. This will facilitate the FTA within African RECs and facilitate weaker states to get on board, thus eliminating the slow effects of variable geometry.

\section{Conclusion and Recommendations}

It is without a doubt that the linear model has led to some successes towards integration in Africa, but its progress is stifled by many factors like poor infrastructure on the continent. This limits the interconnectedness of the continent and makes the cost of trade and business expenses. This paper, therefore, did not set out to entirely discard the linear model but to look for ways of boosting its process. Hence, the proposition of the Functionalist approach, which like the EU would focus on building functional areas within the continent, these functional areas will help facilitate stages of the linear model, like the FTA and CM. An integration is incomplete unless it leads to total unification of a region, hence the proposition of Federalism. Since the African States are wary of losing their sovereignty, a fully functional Africa would have already prepared African countries for supranational leadership because it is inevitable. Additionally, African states will still get to retain some of their power especially when it comes to decision making. This will further enable movement of most RECS from the trapped position of the customs union, to the common market. 
In examining the economic dynamics of regional integration, the paper identifies the benefits of an allinclusive regional and economic integration, such as larger markets as a result of free movement of people and goods that could be harnessed by trading communities within Africa. At the monetary union, the AU will come in to facilitate the formation and implementation of the Single currency and policy convergence, hence the development of the monetary union and finally towards a political union which is the highest level of integration. It was noted that there are also dynamic economic effects which influence member countries' long-term growth rates - the gains which, according to the theory of optimum currency, arise from sharing a currency across countries' borders. The dynamic effects and the gains of having regional economic integration are to curtail mainly from the creation of superior markets by the movement to freer trade under customs unions. On a fundamental level, the joining of an economic integration consolidates markets, making it conceivable to lessen imposing business model power, as more firms from various nations are carried into increasingly serious rivalry with one another.

The advantages related to the unfavourable to customs union's dynamic additions may more than balance any negative static impacts. This paper employed the exploratory research methods, aimed at stimulating more thinking on the subject. This study recommends that it is necessary that integration in Africa does not become elitist which invariably lead to ignoring the views of the people, because then it may be doomed for failure. It also recommends that it is imperative to carry out an empirical study to get governments, institutions and citizens opinions on how they think African integration can be carried out. It is observed in this study that on a fundamental level, an economic and financial combination of integration can join markets, and make it conceivable to diminish restraining infrastructure control, as more firms from various nations are carried into more serious rivalry with one another. It is recommended that in order to reap the advantages related to a customs union's dynamics of economic integration which increases balance and eliminate the negative static impacts, the inclusive linear model should be considered to guarantee economic development across the region in all member states.

\section{References}

Alexandrescu, M. (2007). David Mitrany: From Federalism to Functionalism. Paradigms, 20-33.

Beramendi, P. (2007). Federalism. In The Oxford Handbook of Comparative Politics, 752-781.

Bergmann, J. \& Niemann, A. (2013). Theories of European Integration and their Contribution to the Study of European Foreign Policy. In 8th Pan-European Conference on International Relations, 1-22.

Bolanos, A. B. (2016). A step further in the theory of regional integration: A look at Unasur's integration strategy.

Carbaugh, R. J. (2004). International Economics, 9th edition. Australia. Thomson South-Western.

Chime, C. (1977). Integration and Politics among African States; Limitations and Horizons of mid-term theorizing.

Chingono, M. \& Nakana, S. (2009). The challenges of regional integration in Southern Africa. Journal of Political Science, 3(10), 396-408.

DeRosa, D. A. (1998). Regional Integration Arrangements: Static Economic Theory, Quantitative Findings, and Policy Guidelines. World Bank, Development Research Group, Policy Research Working Paper No. 2007.

Dey, I. (2005). Qualitative data analysis. London: Routledge, Taylor and Francis Group.

Draper, P. (2010). Rethinking the (European) Foundations of Sub-Saharan African Regional Economic Integration: A Political Economy Essay. OECD Development Centre Working Paper, 10(293), 1-34.

Economic Commission for Africa (ECA). (2006). Institutions and Regional Integration in Africa. In ARIA II: Rationalizing Regional Economic Communities, 21-44.

Economic Commission for Africa (ECA). (2004). Assessing Regional Integration in Africa I (ARIA I). Addis Ababa: United Nations Economic Commission for Africa.

Enaifoghe, A. O. \& Adekoye R. A. (2018). South Africa's National Development vis-à-vis Regional Dynamics. Journal of African Foreign Affairs (JoAFA), 5(1), 129-147.

Eskridge, W. N. J., Bednar, J. \& Ferejohn, J. (1999). A Political Theory of Federalism,

Geda, A. \& Kibret, H. (2002). Regional Economic Integration in Africa: A Review of Problems and Prospects with a Case study of COMESA.

Haas, E. B. (1970). The Study of Regional Integration : Reflections on the Joy and Anguish of Pretheorizing. International Organisation, 24(4), 607-646.

Hailu, M. B. (2014). Regional Economic Integration in Africa: Challenges and Prospects. Mizan Law Review, 8(2), 299-332. 
Hamad, H. B. (2016). Neo-Functionalism: Relevancy for East African Community Political Integration? Africology: The Journal of Pan African Studies, 9(7), 69-81.

Hartzenberg, T. (2011). Regional Integration in Africa. WTO Staff Working Paper, (ERSD-2011-14), 1-28.

Hartzenberg, T. (2015). How Can Africa's Regional Integration Agenda Reflect 21st Century Trade Developments? The Journal of the Helen Suzman Foundation, (75), 75-80.

Hazlewood, A. (1967). Problems of integration among African States. In African Integration and Disintegration: Case Studies in Economic and Political Union. London: Oxford University Press.

Hooghe, L. \& Marks, G. (2005). The Neo-functionalist Were (almost) Right: Politicization and European Integration. Web papers on Constitutionalism \& Governance beyond the State, (5).

Hveem, H. (1974). Integration by Whom for Whom, against Whom? On the relationship between neo-classical integration theory, processes of integration and social structure. Cooperation and Conflict Nordic Journal of International Politics, 264-284.

Ibrahim, S. G., Ogbeidi, D. \& Adams, J. W. (2015). An Inter government a list Approach to Regional Integration in Africa: The Efficacy of the African Union (AU). International Journal of Multidisciplinary Research and Modern Education (IJMRME), 1(1), 461-479.

Jawoodeen, E. (2010). A Critical Analysis of the Linear Regional Integration Model, Stellenbosch.

Kühnhardt, L. (2005). African Regional Integration and the Role of the European Union, Berlin.

Kurt, Ü. (2009). Europe of Monnet, Schumann, and Mitrany: A Historical Glance to the EU from the Functionalist Perspective. European Journal of Economic and Political Studies, 2(2), 41-60.

Lindberg, L. N. (1970). Political Integration as a Multidimensional Phenomenon Requiring Multivariate Measurement. International Organisation, Regional Integration: Theory and Research, 24(4), 649-731.

Luke, D. \& Mabuza, Z. (2015). The Tripartite Free Trade Area Agreement: A Milestone for Africa's Regional integration process, Bridges Africa, 4(6).

Magu, S. M. (2014). Dilemmas of collective action: Explaining East African regional integration and cooperation. International Journal of Political Science and Development, 2, 58-67.

McCarthy, C. (2010). Reconsidering Regional Integration in Sub-Saharan Africa. Supporting Regional Integration in East and Southern Africa-Review of Select Issues, (McCarthy 2007), 1-26.

Melo, J. D. \& Laski A. (2015). Will West Africa's Common External Tariff Protect Consumers?

Mitrany, D. (1948). The Functional Approach to World Organisation. International Affairs (Royal Institute of International Affairs 1994), 24(3), 350-363.

Mitrany, D. (1966). A Working Peace System,

Mogalakwe, M. (2006). Research Report. The Use of Documentary Research Methods in Social Research African Sociological Review, 10(1), 221-230.

Ojo, E. O. (2009). Federalism and the search for national integration in Nigeria. African Journal of Political Science and International Relations, 3(9), 384-395.

Qobo, M. (2007). The challenges of regional integration in Africa; in the context of globalization and the prospects for a United States of Africa. Institute of Security Studies, (145), 1-16.

Rothchild, D. (1968). From Federalism to Neo-Federalism. In Politics of Integration; An East African Documentary. Nairobi: East African Publishing House, 1-215.

Sakyi, D. \& Opoku, E. E. O. (2014). Regionalism and Economic Integration in Africa: A Conceptual and Theoretical Perspective,

Schiff, M. \& Winters L. A. (2003). Regional Integration and Development. Washington D.C. Oxford University Press.

Sore, S. Z. (2010). Establishing Regional Integration: The African Union and the European Union. Macalestar International, 25(Article 13), 1-29.

Tanyanyiwa, V. I. \& Hakuna, C. (2014). Challenges and Opportunities for Regional Integration in Africa: The Case of Sadc. IOSR Journal of Humanities and Social Science (IOSR-JHSS), 19(12), 103-115.

Tovias, A. (1992). The theory of Economic Integration: Past and Future.

Tsikata, Y. \& Melo, J. (2014). Regional integration in Africa : Challenges and prospects * A contribution to the Handbook of Africa and Economics. Foundation pour les Etudes et Recherches sur le Development International, 1-24.

Ziblatt, D. (2004). Rethinking the 0-rings of Federalism Puzzle, Theory, and Evidence from NineteenthCentury Europe. World Politics, 57, 70-98.

Zormelo, D. K. (1994). Integration Theories and Economic Development: A Case Study of the Politics and Social Dynamics of ECOWAS. 